\title{
Geostrategic Imperatives of Gwadar Port for China
}

\author{
Fakhar Hussain
}

The increasing demands of energy supplies and limitations of the possession of natural resources of energy have been making every nature of military, economic and diplomatic stratagems of nation states. The demand and supply gap has produced an environment of strategic competition among the leading energy consuming states. China has serious concerns about the likelihood of interruptions in the smooth transportation of oil and gas shipment tankers towards China from Africa and the Gulf region through the Strait of Malacca in relation to attacks by the pirates or terrorists, as $80 \%$ of oil used in China goes through shipping lines of the Strait of Malacca. China desires for reduction of its dependency on the Strait of Malacca and has been making efforts for the development of alternative transit routes. Pakistan has been in the position of bridging the gap by making available the possible shortest transit route for the shipping of energy. China has been looking for alternate prospects to safeguard its energy supplies. In the military and strategic terms, Gawadar may help to monitor the Sea Lines of Communications (SLOCs) originating from the Persian Gulf and bottle neck at Strait of Hormuz. Beijing can aspire to exercise considerable influence in the region, and monitor the Indo-US maritime collaboration in the Indian Ocean. This paper discusses the geostrategic imperatives of Gwadar for China in terms of Chinese quest for maritime, economic and energy security.

Key Words: Xinjiang, Malaccan Strait Dilemma, String of Pearls, Chinese Gibraltar, Central Asian Republics (CARs), Strategic Heart, Golden Bird

* Fakhar Hussain (diplomat786@gmail.com) is currently a Lecturer in Civics at Government Imamia Degree College Sahiwal, Pakistan. He earned his MS Degree in International Relations (IR) from Government College University Faisalabad, Pakistan and MA Degree in Diplomacy \& Strategic Studies (D\&SS) with distinction from University of the Punjab Lahore, Pakistan. His research interests include China-Pakistan Strategic Relations; China-Pakistan Economic Corridor (CPEC); One Belt One Road (OBOR) and International Security. His Research Paper on "China-Pak Economic Corridor (CPEC) and its Geopolitical Paradigms" has been published in International Journal of Social Science, Humanities and Education (IJSSHE), Vol. 1, No. 2. 79-95. 


\section{INTRODUCTION}

The increasing demands of energy supplies and limitations of the possession of natural resources of energy have been making every nature of military, economic and diplomatic stratagems of nation states to be formulated with the priority objective being the uninterrupted admittance to the energy means (Pascu 2011). The economic progression of a state has been closely connected and interrelated with the international trading and energy supplies (Kalim 2016). The energy has been emblematizing the geo-economics and geo-politics of the $21^{\text {st }}$ century (Ahmad, Rubab and Akram 2015). Energy requirement has grown by $95 \%$ throughout the past thirty years and has been expected to increase by additional $33 \%$ in the succeeding fifteen years and about $45 \%$ for the duration of the next 20 years (Ahmad 2009). The economic and military power of a country depends upon oil and the other resources of energy production (Nixon 1980). About 40\% of the consumer products of the world are being transported through the Strait of Malacca and $40 \%$ of the world oil transits across the Strait of Hormuz. Estimates indicate an increase of about $45 \%$ in the global energy demands by 2030, amounting to more than half of the Indian and Chinese requirements covertly leading to an increase of the shipment transportation in the Indian Ocean (Pascu 2011). The demand and supply gap has produced an environment of strategic competition among the states that has almost been led by China (Kalim 2016). The world emerging economies of China and India would have the greatest demands. China has become the world's leading energy consumer by surpassing the USA. Chinese oil imports would exceed to about 7.3 million barrels per day by the 2020 (Pascu 2011). China lacks hot waters seaport giving it advantage regarding maritime transit trade route of $16,000 \mathrm{Km}$ encompassing the additional travelling of 2-3 months that has been required to approach the industrial region of China through the Shanghai seaport (Naseem 2014). China has serious concerns about the likelihood of interruptions in the smooth transportation of oil and gas shipment tankers towards China from Africa and the Gulf region through the Strait of Malacca in relation to attacks by the pirates or terrorists. On the basis of it, China desires for reduction of its dependency on the Strait of Malacca and has been making efforts for the development of alternative transit routes (Joseph 2005). Presently, the shipment containers carrying cargo destined for the western part of China have to travel through a long trading route across the maritime territories of the East Asian states. These merchandises have been further transported to the thousands of miles by land routes towards their destination, especially for the oil tankers that has been relying on the route of the Strait of Malacca through the Gulf being patrolled by the US. Under such circumstances, 
China has been foreseeing the utilization of Gwadar seaport as a docking point for the oil and gas tankers that may provide better control over the shipment activities and the concerns regarding the paradigm of energy security (Neo 2013). Energy security has become lifeline of the economic and military power of the states on account of which the great powers have been trying for the extraction and import of these natural resources through the broadening of the oil and gas pipeline transit routes. The US, Russia and China have shown interests in this region on the basis of its geostrategic significance (Aman 2008). The US, China and India are the main actors that has been trying to enforce their rules in the maritime zone of the Indian Ocean. The race for the security of energy resources and the Strategic Sea Lines of Communications (SLOCs) have determined China and India as two emerging powers which have been investing enormously in the development process of their merchant and combat navies (Pascu 2011). The natural energy reserves of the world have been concentrated in the Middle East and the Central Asian Republics (CARs). Due to the constantly increasing population and industrial development, the countries like China and India need extra energy to come across their demands. Both China and India have been looking for secure, cost effective and continuous supplies of natural energy for the sustaining of their industrial development and progress. Pakistan on the basis of its geostrategic location at the juncture of South Asia, the West Asia and Central Asia has been in the position of bridging the gap by making available the possible shortest transit route for the shipping of energy (Alamgir 2011). The Central Asian Republics (CARs) have been in the possession of enormous natural energy and hydrocarbon reservoirs and have also been significant in the world politics on the strategic grounds (Ahmad, Rubab and Akram 2015). With the disintegration of the USSR and the downfall of Russia, the Chinese government has been pursuing the pragmatic, fixated and indomitable strategies in an impassive mode to be accepted as a world power in the due course of time (Malik 2012). The world has been transformed into a global village due to globalization in real sense of the word, and the process of integration at the regional level is an important facet of the phenomenon. The Central and South Asia have been two imperative regions of the world. Central Asia has been endowed by natural resources mainly the oil and gas reservoirs while on the other hand, South Asia is a region that has been developing rapidly and the possession of its internal energy means is becoming insufficient. The establishment of corporeal infrastructural links and intensification in the trading volumes amongst the Central Asia, South Asia, West Asia and Western China regions would be equally beneficial. China has been looking for alternate prospects to safeguard its energy supplies and Gwadar seaport may be able to provide the most safe and economically feasible substitute 
to interlink with the world (Azhar 2015).

\section{GEOSTRATEGIC POTENTIALITY OF GWADAR PORT}

The geostrategic significant position of Pakistan and its resourcefulness has made it a hot destination for the global entrepreneurs and for that reason China has become the largest investor in Pakistan (Tanoli 2016). Gwadar seaport has been situated at the crossroads of South Asia, the Central Asia and the Middle East regions. It is located close to the Iranian border and lies at the entrance of the Strait of Hormuz, being a main route of world oil supply (Ali 2013). Gwadar will offer two way outlets to the east-west and north-south markets (Khan 2013). The location of Gwadar at the intersection of the South \& Central Asia and the Middle East has made it being the western most interlink in the 'String of Pearls Strategy' by China (Naseem 2014). Geographically, the Gwadar seaport is positioned at the corridor of the Middle East and Central Asian natural resources, as well as in proximity to the consumer market of Asia with $1 / 3$ of the world population, and also at the shortest transit route towards the Southern provinces of China. Gwadar seaport connects five significant regions of the world namely the South Asia, China, the Central Asia, the Persian Gulf, Iran and with a small geographic joining to Russia (Azhar 2015). The Chinese 'String of Pearls' stratagem gathered renowned consideration through the formal transferring of the operating rights of Gwadar port to the state owned Chinese 'Overseas Port Holding Company' (Neo 2013). The evolving influence of China in this region is expedient to its global interests (Azhar 2015) that has been planned to expand, secure and increase the much needed supplies of energy. The Chinese proposal regarding establishment of an oil processing plant at Gwadar and the construction of desired oil pipeline from Gwadar to Xinjiang would supply oil from the Persian Gulf and Africa to the Western region of China by reducing the distance of thousands of Kilometers. The proposed length of oil and gas pipelines from Gwadar seaport to Xinjiang via Pakistan would be $2500 \mathrm{Km}$ while on the other hand, the distance from Xinjiang to the Eastern Chinese seaports of Shanghai and Beijing is $4500 \mathrm{Km}$ (Khan 2013). Also, the distance from Chinese Eastern coast to Kashgar is $3500 \mathrm{Km}$ while from Gwadar, Kashgar is only $1500 \mathrm{Km}$ away (Bokhari 2004). Pakistan provides secure, shortest transit route from Gwadar through Karakoram Highway (KKH) to the Western part of China that has been undergoing an economic move, on the basis of which it would be advantageous to enhance collaboration between the countries (Naseem 2014). With the interlinking of Gwadar seaport and Kashgar through the Karakoram Highway, two enormous supply and consumer markets 
would be connected by transforming Baluchistan and Xinjiang as being pivot of the regional trade and commercial activities (Khan 2013). Gwadar offers China Pakistan Economic Corridor (CPEC), which would serve to be a significant trading route for China, landlocked Central Asian Republics (CARs) and the Middle East. It would be helpful for revival of the ancient Silk Road commercial route that had started nearly 2400 years ago. This trans-regional transit route has been expected to connect about 3 billion people of the region (Hussain 2016). Gwadar seaport has expediently been situated to serve the South and West Asia, Central Asian Republics (CARs) and the Western regions of China in comparison to the other competitor seaports. According to experts, China-Pak close relations will create geostrategic and geopolitical balance in the region (Alamgir 2011).

Gwadar seaport is located in close proximity to the admittance of the Persian Gulf and the Middle East, which have been the biggest source of crude oil for China. Oil pipeline at Gwadar and adjoining the Western China would reduce the time-distance equation required for the transportation of fuel, rather than travelling through the congested channels around Singapore (Naseem 2014). The deep water seaport at Gwadar has been projected as being center of the region on the basis of serving the commercial to and fro traffic from the Central Asian Republics (CARs), Afghanistan, the Middle East, Persian Gulf, South East Asia, Iran and Xinjiang. The enhancement of Gwadar seaport would be capable of immense economics gains for the regional states. The oil and gas resources of these countries may be transported to the globally emerging consumer markets. It will shorten the distance of the Western landlocked regions of China to the sea from $4000 \mathrm{Km}$ to just $2000 \mathrm{Km}$ of the East coast of China and to the South of Gwadar and also, the highways linking it to Afghanistan may further decrease the distance of Pak-Central Asian traffic to about $500 \mathrm{Km}$. The development of Gwadar seaport has been a significant element of an overall initiative by Pakistan for the facilitation of trading links with the landlocked Central Asia that may also work as being energy conduit for Central Asian Republics (CARs), the South Asia and the western China, producing substantial profits through cargo charges for Pakistan. The quest for energy security in terms of smooth supplies has also attracted the attention of China, India, the USA and Russia, on accounts of being part of "new great game" focusing around Gwadar (Fazl-e-Haider 2009). Gwadar has been considered as opening way for China and the Central Asian Republics (CARs) towards the hot waters of Arabian Sea, as Gwadar seaport is at a distance of about $2500 \mathrm{Km}$ and substantiating to be of great benefit for them as the trade may continue during the course of year due to warm waters (Naseem 2014). Gwadar may turn out to be a vital route for China under the emerging geostrategic milieu (Azhar 2015). Gwadar seaport may offer a cost-effective transport of goods 
to the outer market economies as well as an innocuous and shorter route for China. Gwadar seaport will allow China to reach out the region possessing about $48 \%$ of oil and $38 \%$ of the natural gas reservoirs of world. The oil and gas may be carried through this seaport for transportation via road towards the Western regions of China. China is going to adopt the approach of getting cost-reductive and time-saving trading route through Gwadar that would enable the predicted super power to come across its energy supplies. In the similar way, Gwadar seaport may like to be a "Golden Bird" of Pakistan (Tanoli 2016) because it will secure Chinese oil imports by providing a safe and short transit route. Gwadar port will also help China to outspread its existence in the Arabian Sea and the Persian Gulf being source of about 60\% energy imports of China (Khan 2013). The region of Persian Gulf encompasses $60 \%$ of the proven crude oil and $45 \%$ gas reserves of the world (Ahmad 2009). In accordance with the report "Energy Futures in Asia" by Pentagon, Washington perceives Gwadar as part of the "String of Pearls Strategy" by China that seeks projection of its power overseas even though safeguarding the energy supplies and has also been concerned with the strategic influence that China may gain by setting up of electronic surveillance listening post at Gwadar for monitoring of shipment traffic. China has been suspicious that the US may cut off its supplies of oil through the Strait of Malacca in case of any hostility on the issue of Taiwan. Under such circumstances, Gwadar port will enable China to expand routes of crude oil import and may extend presence in the Indian Ocean (Naseem 2014). Washington fears that China has been looking for commercial seaport facilities around the world in order to control strategic energy chokepoints and to create an environment of insecurity jeopardizing the security of shipping vessels at high sea. Furthermore, the location of Gwadar at the opening of the Persian Gulf will be disturbing in the perspective of US conflict with Iran. Chinese presence in Gwadar will countenance not only the admittance and the basing facilities to China in the Indian Ocean but may also the prospects for control of the Strait of Hormuz to make sure the horizontal energy supplies from the West Asia (Kapila 2002). Notwithstanding, economy China has also been facing security concerns that makes "Gwadar-Kashgar" transit trade route significant for Chinese whole sea trade. The shipment vessels travelling through the Persian Gulf have to pass in close proximity to the Indian sphere of influence and through the Strait of Malacca. China is conscious about the vulnerability of its cargo ships during the course of sea passageway and predominantly through the Strait of Malacca being termed as "Malaccan Dilemma" by Chinese (Azhar 2015). 


\section{GEOSTRATEGIC IMPERATIVES WITH RESPECT TO MARITIME SECURITY}

Maritime security has gained worldwide momentum due to the accumulative effects of globalization that has been transmuted into the system of mutual interdependence for economic development and an output by exchange with corresponding productions and natural resources (Kalim 2016). Maritime security has become the highest priority of world powers in the Arabian Sea for ensuring continuous flow of transit trade and the autonomy of navigation (Ahmad 2009). All the littoral states have definite maritime and geostrategic interests varying from state to state on the basis of geopolitical situation of the region. Maritime interests have usually been associated with the safety of seaborne trade for ensuring sovereignty of navigation and safety of the Sea Lines of Communication (SLOCs) and exploitation of the Exclusive Economic Zones (EEZs) while strategic interests emphasizes security and safeguard of seaboard of a state during peace and wartimes (Kalim 2016). On the basis of strategic grounds, Beijing has likely been to maintain largely an economic viewpoint in relation to (IOR) rather than militaristic in order to come across its growing demands of energy supplies, being contingent to the nautical deliveries from foreign nations. With the presence of great powers in the region, there may be incentives for China to maintain permanence at sea for the protection of economic concerns (Neo 2013). The strategic, economic and military potential of Gwadar would bring Pakistan and China in dynamic maritime collaboration in relation to shipment, navigational autonomy, execution of the international laws of sea and coastline defense (Kalim 2016). Gwadar has been dubbed as a crowning jewel in the string of pearls for China on account of its geographical advantages of being $400 \mathrm{Km}$ away from Strait of Hormuz suggesting for strategic and military significance in the light of proposal by China in 2009 to the US Pacific Fleet Commander suggesting that Indian Ocean may be accepted as being Chinese sphere of influence (Neo 2013) assuming that the US may decrease military ships manipulating influence in region with the involvement of allies possessing growing naval powers. Gwadar may present Pakistan with opportunities for capitalization on the Sino-Pak companionship while gaining strategic leverage in connections with India and the US. Bearing in mind the military developments and maritime capabilities of Japan, India and China, the US may be presumed to adopt a policy analogous to the British Empire for the period of the late 19th century (Pascu 2011). Consideration of Gwadar in control of the US, it may serve to be an effective platform for furtherance of the US objectives of maintenance of hegemony, controlling hydrocarbon and mineral 
reservoirs of the Persian Gulf, Central and South Asia as well as containment of China and Russia (Azhar 2015). The Indo-US apprehensions have been growing in relation to involvement of China in Pakistan and have been considered to be a potential threat (Kakar 2014). It is projected that the US may be relying on Indian and Japanese naval support in order to counterweight influence of China in the designated maritime regions. India has been establishing naval bases and strategic listening posts at Madagascar, Mauritius and Seychelles Islands on account of its consideration of Pak-China alliance a tangible threat being materialized due to construction of Gwadar seaport as a bid to allow for control of Strait of Hormuz (Pascu 2011).

In case the Strait of Malacca has been blocked by the US, Gwadar may be able to serve as an alternative trade route for China in the Indian Ocean and to the West Asia. In strategic and military expressions, Gwadar could be supportive to China for monitoring Sea Lines of Communications (SLOCs) originating from the Persian Gulf and being a source of about 60\% energy requirements of China. Gwadar will also make available to China a strategic listening post for observing naval activities of India round the Persian Gulf and the Gulf of Aden (Malik 2012) and Beijing would also desire to exercise substantial influence by monitoring the US naval activities in the Persian Gulf region, nautical activities of India in the Arabian Sea, and the future Indo-US maritime collaboration in the Indian Ocean (Naseem 2014). China is conscious about significance of its mercantile development and militaristic capabilities on the basis of which it may be able to counterbalance optimizing influence of India (Pascu 2011). China has apprehensions regarding growing influence of India in the Arabian Sea, predominantly since Indo-US civilian nuclear deal that has been worrisome for Pakistan and China regarding long term strategic and economic regional interests (Khan 2013). Gwadar seaport has gained extreme consideration from very beginning on the basis of strategic position and the establishment of strong militaristic ties between China and Pakistan (Ali 2013). The security of Sea Lines of Communications (SLOCs) is of enormous significance for countries having seaborne transit trade (Kalim 2016). Gwadar has geostrategic prominence by lying across the (SLOCs) emanating through strategic chokepoint of the Strait of Hormuz, that has been a passageway of about 13 million barrels of oil transport on daily basis (Malik, 2012). The Sea Lines of Communications (SLOCs) have been interlinking the whole world (Kalim 2016). Gwadar may help for monitoring Sea Lines of Communications (SLOCs) emanating from the Persian Gulf and bottleneck at the Strait of Hormuz (Malik 2012). Maritime Security relatively lays emphasis on security of the Sea Lines of Communication (SLOCs) (Kalim 2016). India has viewed China as a potential threat and has been surrounded from three 
sides of Tibet, Myanmar and Pakistan by Chinese influence. Iran may also be viewing China as a threat due to Gwadar being thought of depriving Iran of its economic profits (Kakar 2014).

New Delhi perceives the Arabian seaport of Gwadar as a naval base of China, which may likely to be developed into a strategic homeport naval base equipped with nuclear submarines and aircraft carriers with the passage of time. Independent scholars believe that presence of China in Gwadar will frustrate Indian strategy of dominating the regional waterways (Fazl-e-Haider 2009). The Indian navy has been struggling transformation from being littoral naval force to the largest blue waters naval force of the region (Kalim 2016). India navy has been consolidating military positions in Andaman and the Nicobar archipelagos for exertion of control to the Strait of Malacca (Pascu 2011). India's topmost priority is the accomplishment of dominant power status in the Indian Ocean with the support of the US and Australia (Kalim 2016). China has been getting hold of the strategic seaports in Gwadar, Bangladesh, Sri Lanka, Burma, Thailand, Cambodia, and South China Sea etc. under the String of Pearls Strategy. The location of these seaports depicts a figure of string (of pearls) on the world map which may have been considered as Chinese line of defense for controlling movement of oil, as $80 \%$ of oil utilized in China has been transported through these shipping lanes of the Strait of Malacca (Naseem 2014). In comparisons with the "String of Pearls" philosophy, Chinese narrative inclines to portrait the strategy of Indian Ocean in wide-ranging economic and marine security perspectives. India and the US have been holding dominance over the significant shipment traffic lanes for an extensive period of time by posing a Malacca Strait dilemma for China (Neo 2013). The naval activities of India in areas of the Persian Gulf and the Gulf of Aden have remained an eye sour for China. The Director General of Staff Logistics Department of the Chinese Navy Mr. Zhao Nanqi issued a secret memo explaining the strategic planning of People's Liberation Army (PLA) for enhancement of control over the Pacific and Indian Oceans in the light of "high-sea defense" policy to be pursued through its "String of Pearl Strategy" (Malik 2012). China has been in the need of a balancer to counterbalance India for dilution of the effects of its hegemonic emergence. Pakistan is the country that can act as balancer for China in the region. In this perspective, China has been well aware of the significance of Pakistan card. (Rana and Mahmood 2015). Pak-China joint project of the construction of Gwadar seaport has meant for providing logistics marine base to Chinese navy that may enable China for maintaining its existence in the Indian Ocean. The emergence of Pak-China strategic and naval collaboration has become inevitable for counteracting the militaristic Indo-Israel nexus (Kalim 2016). The establishment of a naval base at 
the opening of the Indian Ocean may be helpful to China for observing the hegemonic designs of India in the region (Malik 2012). In the worst case scenario of a crisis with India, Gwadar seaport may provide Pakistan with strategic depth to Naval and the commercial resources. Gwadar is situated in close proximity to the Indian Ocean highways that has been a corridor of about $80 \%$ of global trade of oil and raw materials transported to Europe, America and the Far East. Therefore Gwadar is strategically positioned at a strategic point to create disruptions in smooth flow of commercial trading, as India and the U.S look at Chinese investment in the construction of Gwadar seaport with similar perceptions, since the time China has been consolidating footholds in the Indian Ocean with the establishment of seaports originating from China Sea to the Persian Gulf (Shahnaz 2015).

The US perceives China as being as a key regional competitor (Azhar 2015). The US has been concerned about swift growth of Chinese might and influence in Asia. Pentagon is worried regarding Chinese monitoring of the US naval activity in the Persian Gulf possibly through Gwadar that may also fuel the suspicions towards Pak-China relations being felt by the US since long (Fazl-e-Haider 2009). Washington has been viewing Gwadar as being "Chinese Gibraltar" (Azhar 2015). The naval presence of China at the significant energy chokepoint of the Gulf may also check the Indo-US dominance of the Indian Ocean (Richard 1992). Some of the scholars have argued that Gwadar seaport may become a naval base of China in the Indian Ocean enabling Beijing for monitoring of Indo-US nautical activities on the basis of which it can also been called as the western-most link China under its "String of Pearls Strategy" (Ali 2013). Gwadar seaport may be capable of providing a strategic listening outpost to China for observing the US naval activities in the Persian Gulf some $460 \mathrm{~km}$ from Karachi, being further away from Gujrat and Mumbai Naval bases of India (Malik 2012). Consideration of the US for having admittance of China to Gwadar will make it capable of getting rid of the long and vulnerable (SLOCs), that may help its economic and marine potential (Azhar 2015). In terms military and strategic perspectives, Gwadar may help China for monitoring (SLOCs) emanating from the Persian Gulf. It is estimated that $60 \%$ of required energy supplies of China has been coming from the Persian Gulf and transported through this transit trade route. The naval presence of China may likely to strengthen coastline defense of Pakistan (Malik 2012). Gwadar seaport will make the availability of a frontward base to China for monitoring of the US naval activities in the Persian Gulf and Indian nautical designs in the Arabian Sea. Analogous situations may also prevail in the area of the Bay of Bengal and the Coca Island in Myanmar where China has established the facilities to monitor maritime activities of India and the test firing of missiles in Orissa 
(Naseem 2014). With the stationing of Chinese marines at such a vital position, China may be in the situation of monitoring activities by the US naval forces (Azhar 2015) as well as it will also have the capability of striving for achieving the status of being a world naval power (Yeuh-Yun 1972). Pakistan has made known of its intentions regarding development of Gwadar with the capabilities of militaristic projections to be built as a naval base with the help of China. Pak-China strategic alliance has created trust for the facilitation of inter-operability between them predominantly vis-à-vis India. Gwadar seaport will facilitate China with strategic footholds in Arabian Sea and the region of Indian Ocean. Gwadar may prove to be a daunting prophecy as being full-fledged and an offshore naval base of (PLAN) of China (Neo 2013). Gwadar has been considered as third largest seaport in the world that may be able to accommodate the submarines and defender naval ships of China for ensuring safety of the Arabian Sea and security of its smooth supply lines of energy, as well as it would also help Pakistan for strengthening naval forces of Pakistan against outmatched expansion of Indian navy (Kalim 2016).

\section{GEOSTRATEGIC IMPERATIVES WITH RESPECT TO THE ECONOMIC PERSPECTIVE}

The commercial activities of world have been experiencing fast intensification on account of which maritime politics has got to become complex and multidimensional (Tanoli 2016). Globalization has brought about modifications in economy of world and has led the civilization towards the creation of a "Borderless Civilization". The phenomenon has substantially enlarged nautical trading volume from, 2.37 billion tons of cargo to 5.88 billion tons (Stopford 2005). The emerging economy of China and proximity of seaport to the Strait of Hormuz is a pivotal feature of Gwadar making it prominent in the world (Kalim 2016). Pakistan has been positioned at the convergence of three significant regions of South Asia, Central Asia and West Asia providing for the shortest admittance of sea to the landlocked Central Asian Republics and Western China. The strategic linkages of communication and trade passing through Pakistan may transform it into an economic corridor giving boost to the inter-regional commercial activities (Anwar 2011). The utilization of Gwadar seaport as a land based interlink may be of help to China for the improvement of growing transit trade with the Central Asia, the Middle East and Africa to the extent that it may reduce 10'000 $\mathrm{Km}$ maritime distance to about $2500 \mathrm{Km}$ (Khalid 2009). The development of Gwadar seaport and Special Economic Zone (SZE) at Kashgar may have potential 
for revival of ancient Silk Route. The inland connection of Gwadar to Kashgar through Indus and Karakoram Highway (KKH) across the landlocked (CARs) will provide opportunities for regional trade (Khan 2013). It has been viewed that Gwadar seaport will bring about economic and strategic benefits by securing Sea Lines of Communications (SLOCs) in the Indian Ocean with regard to the International Trade (Shahnaz 2015). Economic growth in modern times is dependent on conditions of infrastructure networks for trading and transportation activities. Investments by China in agro-business, tele-communicational network, extraction of natural mineral resources i.e. oil, gas, uranium, gold and copper will enhance exports, helping for the boost of Central Asian market economies (Brohi 2016). Pakistan and China has planning for interconnection of Gwadar through Indus Highway (IH) with Ratodero and (KKH) leading towards Kashgar about $414 \mathrm{Km}$ from Pak-China border of Sost-Tashkurgan and further going through Tajikistan, Kyrgyzstan and Kazakhstan, on account of which all of these states have become signatories of quadrilateral agreement of trade for the utilization of regional trade route (Khan 2013). China, Pakistan, Kazakhstan and Kyrgyzstan have been agreed for initiation of bus service for enhancement of trade and promotion of people-to-people contact (Anwar 2011). China will establish a "Special Economic Zone" (SEZ) in Gwadar for manufacturing of industrial goods to be exported to Africa (Rana and Mahmood 2015). Shanghai and the other eastern seaports of China are $3000 \mathrm{Km}$ away from western manufacturing centers while on the other side Gwadar will provide such entrance to seaport at a distance of $1500 \mathrm{Km}$ (Hussain and Hussain 2017). The investment of liquid cargo passing through pipelines will be amounting to (2 to 2.5 billion U.S \$ Gwadar), (3.3 billion U.S \$ the Caspian Region) and (35 billion U.S $\$$ China) correspondingly (Malik 2012). China could couple its economic growth by enchanting the control of Central Asian Republics (CARs). China has been trying for creation of a knock-back to the US for magnification of control in the region (Ahmad, Rubab and Akram 2015). Kashgar has become a destination of the world's biggest commercial spot of traditional Sunday where 150'000 people from Central Asia come for the exchange of their commodities to Chinese counterparts (Bhavna 2012).

The transfiguration of Kashgar into commercial and industrial pivot will result into interconnection of inland areas of China to Pakistan and Central Asia. In the due course of time, Kashgar will be capable of becoming platform for promotion of trade and economic collaboration between Pakistan and the Central Asia (Khan 2013). With the completion of Gawadar-Kahghar economic corridor is and its further extension to Afghanistan, it will make available incentives to (CARs) by means of diversion of their trade to Gwadar (Azhar 2015). Kashgar Special 
Economic Zone will be a project of multi-billion dollars meant for imports and exports coming from Kashgar would be passing through Pakistan towards the Arabian Sea (Khan 2013). The construction of a railway line alongside (KKH) linking Pakistan and China has been considered an integral part of China-Pakistan Economic and Energy Corridor (Alamgir 2011). There may be exemption of income tax for five years to entrepreneurs in Kashgar Economic Zone (KEZ) giving economic opportunities for business community of Pakistan. The progress of Kashgar as (SEZ) will result in the up gradation of (KKH) through Indus Highway (IH), linking it to Gwadar that will be instrumental for economic integration at regional level. In this way, Kashgar would be able to serve as commercial engine for backward areas of Xinjiang and Pakistan (Khan 2013). $\mathrm{KKH}$ will provide the straight transit route for transportation of products manufactured in China. It may also serve to provide inland transport route for trade prospects between China and India (Alamgir 2011). Gwadar may be in close proximity to Xinjiang rather than any other saltwater seaport in China, on the basis of which, it will decrease transaction cost levied on the to and fro trade from Xinjiang (Anwar 2011). The proximity of Xinjiang to Gwadar will make it viable and cost-effective to China for carrying out of trade through the seaport of Gwadar which has been situated at the pivot of the Gulf region, the Central Asia, Africa and Europe (Fazal-e-Haider 2009). Gwadar will offer a strategic position to China in the Caspian Region rich in energy resources thus giving a substitute trading route for Chinese province of Xinjiang for utilization as a transit trade route through deep seaport of Gwadar. The economy of China has been expanding annually at a rate of 9\% (Malik 2012). Chinese investors has opportunities for banking, finance, alternative energy, power generation, Information Technology, engineering, textile industry, agriculture, food processing, fruit, livestock farming and dairy products (Khan 2013). Beijing will take delivery of cargo to and fro from Gwadar alongside Karachi to Peshawar routes. The network of railways may be used for oil supplies from Persian Gulf to Xinjiang. The internal railways network of Pakistan will also provide access of China to Iran. Another significant part of integration process is the west Chinese Uighur autonomous region of Xinjiang connecting rest of China to the Central Asia. The province of Xinjiang accounts for $80 \%$ of Chinese volume of trade with the Central Asia (Anwar 2011). China has invested in Xinjiang and its adjacent areas in the manufacturing units while the transportation of energy resources and raw materials to the industrial zones and the export of productions is a matter of concern for the China and this is where Gwadar may have a significant role to play in solving the predicaments (Azhar 2015). Xinjiang lies $4500 \mathrm{Km}$ away from east coast of China but about 2500 $\mathrm{km}$ from Gwadar (Hussain and Hussain 2017). Chinese province of Xinjiang made 
a trading of 33 billion US $\$$ during 2013 in comparison to 22.8 billion US $\$$ for the previous year (Azhar 2015) that may stimulate development process of the backward region of Xinjiang in China (Naseem 2014). Baluchistan and Xinjiang both of the regions have troubled history due to social unrest on the basis of slow economic development and growing inequality in relation to other parts between the two states. The economic growth and opportunities through Gawadar-Kashgar interlink will help the people of provinces for joining of mainstream to the national progress (Khan 2013). The future planning for establishment of oil and gas pipelines crossing through Baluchistan may enhance strategic importance of Pakistan. Gwadar seaport will attract investment opportunities and bolster progress of country by serving as economic and energy corridor for the Central Asia, West China and South Asia earning revenue in transit fees for Pakistan. The Chinese quest for security of smooth energy supplies and geostrategic constraints has attracted the attention of US, India and Russia being part of "New Great Game" focusing around Gwadar (Fazl-e-Haider 2009).

China has its own lengthy seacoast, but the extent of the country is so enormous that the western areas have been far detached from the seaboard. With the growth of China in economic and military statures, it needs maintenance of peace and prosperity within its boundaries (Azhar 2015). China has been trying for the development of Western areas at par with the Eastern regions in relation to decrease the economic gap and the internal exodus from West to East within China (Naseem 2014). China intends to develop its western parts and thus has been building infrastructure of transportation network of roads, gas pipelines and railway tracks in Pakistan offered by China through a trade and energy corridor (CPEC) via Gwadar seaport and interlinked to the inland roads. Under the projected (CPEC) plan crude oil may be imported from Middle East, put in refineries storage at Gwadar and would be transported to China via oil pipelines, highway roads, and railway. Some Western and Indian experts maintain that China desires foothold in Gwadar for the strategic purposes (Qasim 2016). Decision of China for financing the construction of Gwadar seaport and the coastal highway road linking to Karachi would help the plans of development of Western China (Alamgir 2011). The chief project being, the construction of a deep seaport at Gwadar has been to enable high volume shipment movement to and fro from noncoastal the Central Asian Republics (CARs). The port may also contain exchange services in order to allow for the transportation of natural gas as a closure point for TAPI natural gas pipeline project. The secondary portion of project would be a coastline highway linking Gwadar to Karachi, estimated construction cost of about $\$ 200$ million may be financed solely by the China. In this way, Gwadar would serve as a seaport of entrance for the oil and gas to be 
transported by inland transit route towards the Western regions of China. Bearing in mind the facets like, vicinity to the Central Asian Republics (CARs), the existence of Lop Nur nuclear test site and its admittance to warm waters from side to side with the ancient silk route and presence of oil, the government of China has adopted an approach of "Go West" policy for the economic development and prosperity of Xinjiang province (Ahmad, Rubab and Akram 2015). Gwadar seaport will provide an option for China for utilization of the shortest route to the Persian Gulf and the Gulf of Aden by traversing a distance of $2500 \mathrm{Km}$ through the Silk Route. Pakistan, China and the Central Asian Republics (CARs) have planned for development of a network of communication infrastructures from the Caspian Sea in West towards Xinjiang in the East, and to be converging at Gwadar in the South (Malik 2012). China has interests in the monitoring of energy supply routes for shipping vessels through the Persian Gulf and opening of alternative transit trading routes via Pakistan serving for autonomous region Xinjiang of China (Fazal-e-Haider 2009). Beijing aims to take advantage of the proximity of Gwadar to the international trading routes towards Central Asian Republics (CARs) and Xinjiang (Naseem 2014). Gwadar will be able to provide communication and the trading interlinks with the outer world round the year. There is no denying to the fact that due Gwadar seaport has potential for becoming a doorway for Central Asia and Xinjiang lying $4500 \mathrm{Km}$ away from the east coast of China and about $2500 \mathrm{Km}$ from Gwadar, which would help China for external trade through Gwadar seaport (Hussain and Hussain 2017).

\section{GEOSTRATEGIC IMPERATIVES WITH RESPECT TO THE SECURITY OF ENERGY SUPPLIES}

Maritime transportation has constantly been having the highest occurrence worldwide by the ratio of $90 \%$ consumer and $65 \%$ of petroleum products are carried through seas. The Indian Ocean has been accounting for half of container traffic in the world and 70\% of petroleum products have been passing through Indian Ocean on the way from Middle East towards the Pacific (Kaplan 2009). China has not any hot waters seaport that could be used round the whole year. The seaport of Shanghai has been $4500 \mathrm{Km}$ away from industrial areas of China, while Gwadar would be at a distance of about $2500 \mathrm{Km}$ from China and that being port of hot waters, it will be functional throughout the year (Alamgir 2011). The quest for security energy supplies has turned India and China into competitors in the game of global energy politics (Fazl-e-Haider 2009). China has been adopting an approach for interlinking its western and southern regions through 
admittance to warm waters with the establishment of oil and gas pipelines from the CARs to ancient Silk Route transit trade route (via Pakistan) through Chinese province of Xinjiang (Malik 2012). The Central Asian Republics (CARs) and South Asia has been rich in hydrocarbon resources on the basis of which Multinational Corporations (MNCs) as well as regional and global powers have interests for the utilization of regional oil and gas reservoirs. The oil refinery funded by China at Gwadar will be able to refine about 21 million tons oil per year and may be transported to Kashghar through a pipeline. The Northern transportation routes and outlets are not appropriate for export of hydrocarbon resources of Central Asian whereas substitute lay in South through Pakistan and Afghanistan being point of convergence. Gwadar located in Southern Baluchistan has been expected for becoming terminus of projected gas pipelines emanating from Turkmenistan's fields of Daulatabad, Iranian South Pars fields or from Qatar. The race for having control of prescribed oil and gas reservoirs may be the part of a new great game which has become complicated with the presence of China in Gwadar near proximity to the Strait of Hormuz (Fazl-e-Haider 2009). The presence of Gwadar at corridor of the Gulf States rich in oil and gas productions may speak volumes regarding its significance (Tanoli 2016). China has strategic interests to reach out blue waters of the Arabian Sea reflecting tactical moves by China in Gwadar (Naseem 2014). Gwadar is situated about $72 \mathrm{Km}$ away from Iranian borderline, $320 \mathrm{Km}$ from the Cape al-Hadd in Oman and $400 \mathrm{Km}$ from Strait of Hormuz being passageway of $40 \%$ oil of the world. Gwadar deep water seaport has been envisaged as being a hub port of region serving for commercial traffic to and fro from the Central Asian Republics (CARs), Afghanistan, Middle East States, Persian Gulf region, Chinese Xinjiang, Iran, and the South East Asian countries. The Strait of Malacca and the Strait of Hormuz have been strategic energy chokepoints in the Indian Ocean and the Arabian Sea (Kalim 2016). The Strait of Malacca has been passageway of about $85 \%$ of oil and gas resources making their way towards China due to which it has gained significance for China (Pascu 2011) and accounting for $1 / 3$ of Chinese oil imports (Azhar 2015). China's $80 \%$ oil import has been flowing through the Strait of Malacca being considered as insecure transit route and notorious for pirates. The position of Gwadar to the opposite of the Strait of Hormuz may provide an alternative for China to the Strait of Malacca. Gwadar seaport will offer a transit terminal of crude oil imports coming from Iran and Africa to Xinjiang province of China (Naseem 2014). The Strait of Hormuz has been facilitating and interlinking the trade between different regions of world. The Strait of Hormuz adjoining the Indian Ocean and Persian Gulf has prominence in the world as being main corridor of energy supplies in the world than other energy routes (Kalim 2016). In relation to the import of oil 
from Middle East, one should have control over energy chokepoints of the Strait of Bab el Mandeb, the Gulf of Aden, the Strait of Hormuz, the Gulf of Oman and the Strait of Malacca have been of strategic significance (Pascu 2011).

The closing of Strait of Hormuz may cause disruption of nautical trade with the rise of global oil price (Kalim 2016). The Strait of Bab el Mandeb interlinks energy chokepoints of the Arabian Sea and the Red Sea leading towards Suez Canal (Ho 2011) from where half of the trade of world has been routed (Ahmad 2009). Gwadar has significant position due to close proximity with the chokepoint of the Strait of Hormuz and having high density of oil shipment traffic in the (IOR) (Neo 2013). Due to the prominence of Indian Ocean for transportation of energy supplies, drug trafficking and pirates the US may continue monitoring and policy of its control in the region. The US has been maintaining its fleet in Indian Ocean for controlling commercial hot spots through the naval base at British Diego Garcia (Pascu 2011). The (IOR) with maximum tonnage of goods has been known as imperative corridor of trade and energy accounting for $80 \%$ transport traffic of petroleum throughout the entire world (Cordner 2011). The factor energy supply has multiplied prominence of Indian Ocean Region (Kalim 2016) and within the region of Indian Ocean North Arabian Sea has been acting as the strategic heart by connecting energy jugulars of world (Azhar 2015). The energy supply demand has been leading the energy politics in the Indian Ocean (Kalim 2016). Gwadar will provide strategic footholds to China in the Indian Ocean and the Arabian Sea by making it capable of monitoring shipments of energy passing through the Persian Gulf (Naseem 2014). The energy chokepoint of the Strait of Hormuz has become a key for facilitation of energy flows of world through the Persian Gulf (Kalim 2016) as $80 \%$ oil tankers of world has been passing through the Persian Gulf and 45\% movement of oil being taking place through Strait of Hormuz (Khan 2013). The US, China, Europe, Japan and other countries import their crude oil supplies from Gulf region (Das 2009). Majority of oil and energy supplies of (LNG) is being exported through this chokepoint to the US, China, Western Europe and Asian countries (Kalim 2016). Gwadar means potential staging ground for Beijing in order to exercise influence alongside the shipment traffic lane of the Gulf because $60 \%$ energy demands of China streams through the Gulf region that China has been using currently for importing oil from the Middle East paying huge transport cost for distance of $16^{\prime} 000 \mathrm{Km}$. Gwadar will enable China to reduce the distance to $5000 \mathrm{Km}$ and may cut down to time distance equation by taking up to 45 days in order to reach out market economies of Europe via the Middle East (Tanoli 2016) and it is also evident that energy transportation through the Persian Gulf and the East African States via Gwadar may decrease the distance of 15 '000 Km to $2500 \mathrm{Km}$ (Khan 2013). Gwadar has been going to emerge as direct 
route to market economies of the Gulf and Africa. The Chinese shipping oil vessels will have to travel about 10 '000 $\mathrm{Km}$ under the existing maritime trade route by passing through the South China Sea, the Pacific Rim, the Strait of Malacca and Sri Lanka, while on the other hand Gwadar will turn the distance in to 2500 $\mathrm{Km}$. The presence of China at Gwadar will help it for keeping an eye on the transportation of oil in the Persian Gulf as well it would be an alternate to Strait of Malacca for China in order to have access to Asia, Europe and Africa (Malik 2012). China has to follow long and insecure trade route for Africa through the Indian Ocean and the Strait of Malacca and diversion of the trade towards Gwadar could be providing economical and secure transit route for China (Azhar 2015) on account of it, oil imports of China from Middle East and Africa would no longer be reliant on the Strait of Malacca (Yan 2012). Gwadar seaport located near the Strait of Hormuz may have bigger strategic importance for Beijing that will help for acquiring presence to China in Arabian Sea and the Indian Ocean for monitoring the US naval activities and the Indo-US maritime collaboration. The oil shipment tankers of China on an average voyage take 20 days to reach the Gulf, however with the completion of (CPEC) projects including high speed rail and road infrastructures across Pakistan would be able to reach Gwadar being on the opening of the Gulf within the time of 48 hours (Hussain and Hussain 2017). Xinjiang province has been lying about $4500 \mathrm{Km}$ from the east coast of China but only $2500 \mathrm{Km}$ from Gwadar due to which Pakistan could be able to act as transit facilitator by giving access to China towards Central Asian market economies and energy resources (Mehmood-Ul-Hassan 2006).

\section{CONCLUSION}

It is imperative to conclude that geostrategic location of Pakistan and its geopolitical fixations have been quite substantial that has attained enormous significance for national security. The geostrategic position of Gwadar in the Arabian Sea could be capable of facilitation to the electronic surveillance for monitoring of the naval activities throughout the Indian Ocean and Arabian Sea. Strategically Gwadar has been situated between three progressively significant areas of the world, namely the Middle East, being rich in oil, the South Asia overwhelmingly populated and (CARs) the Central Asian Republics being emerging economically and enriched by natural resources. This geographical locality imparts Gwadar Seaport to be very essential strategic place in the region. It has found to be located at a distance of $400 \mathrm{Km}$ away from Strait of Hormuz which has remained to be a strategic energy chokepoint and one of the main supply lines 
of oil to the world where 16-17 million barrels (MB) of crude oil has been routed annually. Gwadar may not only work for economic growth of Pakistan but would also be responsible for prospects regarding boosting of the economic benefits and maximization of advantages through strategic position in close proximity to the Sea Lines of Communications (SLOCs) in the Indian Ocean and Strait of Hormuz in future. Gwadar Seaport has pertinent importance with reference to trading linkages to UAE, CARs, the region of Persian Gulf, Eastern Africa as well as Northwestern regions India. Due to the locus, and unfathomable maritime natural features of Gwadar Seaport, it has also been accepted by the Asian Development Bank (ADB) as an alternative seaport for ports of Persian Gulf region in relation for handling of large shipment oil tankers and shipping vessels. The Asian Development Bank (ADB) has characterized Gwadar Seaport as an alternate to Dubai World Port of (UAE), which is out of the chokepoint and the Strait of Hormuz and that Gwadar has been capable of handling larger ' $S$ ' class cargo ships and oil vessels. Pakistan has been situated at the intersection of South, West \& Central Asia, being three important regions of the world, providing them the direct admittance to the maritime for all the landlocked Central Asian Republics (CARs) as well as to the Western part of China. The Strategic Lines of Communication (SLOCs) and trading linkages between the South, West \& Central Asia have been passing through Pakistan that would transform the State into a commercial pivot in terms of giving enhancement to the inter-regional economic activities. Being a trading center for the whole region Gwadar Seaport having been equipped with the contemporary shipment handling would serve the consumer markets of Asia in order to meet the growing challenges of international trade. The Central Asian Republics (CARs) have been looking for a feasible admittance to the outer world and in this way the best option remains the Gwadar Seaport. The Central Asian States have been depending on Russia to transport their goods and natural resources, and have remained in the need of their access to the outer world. In relation to it the short and most viable link can be the deep waters of North Arabian Sea, either through Iran or Pakistan. Due to the unpleasant relationship of Iran with the Western world and the Gulf monarchies, the Gwadar Seaport of Pakistan has been supposed to be the preferred option of the world for linking to the CARs. There may have been two possible routes that could be available to the CARs, one through Iranian port of Chahbahar and the other by Pakistani Seaport of Gwadar. The European Nation States have been struggling to reach out this region rich in mineral and hydrocarbon resources through the Caspian Region prior to other key actors via Gwadar and Afghanistan. The geographical position of the seaport and the willingness of China to help in building and operationalization of the port have 
attracted responsiveness of the regional and extra-regional players equally. The accomplishment of Gwadar Seaport depends upon its utilizations by the Central Asian Republics (CARs), South Asia and China that will create employment prospects and offer enormous economic activities which would directly be transformed into the regional progress and prosperity. China has been strengthening relationship with the Central Asian Republics (CARs) being rich in oil and gas resources because the domestic energy resources of China are not sufficient for growing energy supplies. Gwadar would be able to provide inland oil supply transit route to China being controlled by an all-weather friend Pakistan that will reduce the distance of several thousand $\mathrm{km}$ between eastern China and Gwadar to China. Gwadar seaport will provide energy security to the oil shipments of China posing challenge for Indian domination in the (IOR) and that militarization of seaport may allow China for affirmation of naval presence in (IOR). In the worst case scenario of a conflict, the use of Gwadar and its adjacent airstrip as military base for air, surface and sub-surface fleets could empower China to interdict the Indian tankers and may obstruct the delivery of energy supplies.

\section{REFERENCES}

Ahmad, Azhar. 2009. "Maritime Security Post-9/11: Challenges and Response." Journal of the Institute of Strategic Studies of Islamabad XXIX (2\&3), 86-100.

Ahmad, Mughees, Musharaf Rubab, and Sidra Akram. 2015. "Geo-Strategic Analysis of Central Asia and Intrests of Pakistan." Journal of Grassroots 49(2), 144-151.

Alamgir, Muhammad. 2011. "Strategic Importance of Gwadar Port for Pakistan." (September 16). Accessed at http://muhammadalamgir.wordpress.com/ 2011/09/16/strategic-importance-of-gwadar-port-for-pakistan/ (December 18,2019).

Ali, Ghulam. 2013. "China's strategic interests in Pakistan's port at Gwadar." East Asia Forum. (March 24). Accessed at http://www.eastasiaforum.org. (April 17, 2017).

Aman, Shahida. 2008. "The Economic and Geo-Strategic Importance of the Caspian Sea." Journal of Central Asia 63(Winter), 1-15.

Anwar, Zahid. 2011. "Development of Infrastructural Linkages between Pakistan and Central Asia." A Research Journal of South Asian Studies 
26(1), 103-115.

Azhar, Ahmad. 2015. "Gwadar: Potential and Prospects." Pak Institute for Conflict and Security Studies (PICSS) (January 29). Accessed at http://www.picss.net. (October 23, 2019).

Bhavna, Singh. 2012. "China's Modernization Rush: Kashgar at Crossroads." Institute of Peace and Conflict Studies (IPCS) (January,16). Accessed at http://www.ipcs.org/focusthem. (November 15, 2019).

Bokhari, Imtiaz. 2004. "The US, Oil and Geopolitics of the Persian Gulf." IPRI Journal IV(2), 51-55.

Brohi, Nasurullah. 2016. "CPEC The Real Game Changer For Central Asia." (June 28). Accessed at http://www.eurasiareview.com/28062016-cpec-the-realgame-changer-for-central-asia/ (October 19, 2019).

Cordner, Lee. 2011. "Progressing Maritime Security Cooperation in the Indian Ocean." US Naval War College Review64(4), 68-88.

Das, Pratim. 2009. "Coastal and Maritime Security: Two sides of the same coin." Indian Defence Review (Jan-March 1). Accessed at http://www.indian defencereview.com. (March 5, 2019).

Fazl-e-Haider, Syed. 2009. "Gwadar: An Emerging Centre of the New Great Game.” ISPI Policy Brief 162 (October, 10). Accessed at http://www.ispion line.it. (December 19, 2019).

Ho, Joshua. 2011. "Critical Sea Lines in the Indian Ocean Region." JSTOR. Accessed at http://www.jstor.com/stable/resrep05921.11. (April 23, 2019).

Hussain, Fakhar and Mezhar Hussain. 2017. "China-Pak Economic Corridor (CPEC) and its Geopolitical Paradigms.” International Journal of Social Science, Humanities and Education 1(2), 79-95.

Hussain, Rafaqat. 2016. "Gwadar in Historical Perspective." Muslim Institute (March 18). Accessed at www.muslim-institute.org (22 April, 2019).

Joseph, Mallika. 2005. "India-China Strategic Partnership: Implications for US and Pakistan." Institute of Peace and Conflict Studies (IPCS) (April 25). Accessed at http://www.ipcs.org/comm_select.php?articleNo=1711. (December 22, 2019).

Kakar, Tariq. 2014. "Strategic Importance of Gwadar Port." (June 15). Accessed at http://thebalochistanpoint.com/strategic-importance-of-gwadar-port / (July 18, 2019).

Kalim, Inayat. 2016. "Gwadar Port: Serving Strategic Intrests of Pakistan.” $A$ Research Journal of South asian Studies 31(1), 207-221.

Kapila, Subhash. 2002. "Pakistan and China Relations Post September 11, 2001." South Asian Analysis (August 10). Accessed at http://www.saag.org/pape rs6/papers505.html (July 5, 2019). 
Kaplan, Robert. 2009. "Centre Stage for the Twenty-first Century: Power Plays in the Indian Ocean." Foreign Affairs (March 1). Accessed at http://www.foreignaffairs.com (September 16, 2019).

Khalid, Mumtaz. 2009. History of Karakoram Highway, Volume II. Rawalpindi: Hamza Parvez Printers.

Khan, Shabir. 2013. "Geo-Economic Imperatives of Gwadar Sea Port and Kashgar Economic Zone for Pakistan and China." IPRI Journal XIII(2), 87-100.

Malik, Hassan. 2012. "Strategic Importance of Gwadar Port." Journal of Political Studies 19(2), 57-69.

Mehmood-Ul-Hassan, Khan. 2006. "New Heights of Pak-China Ties.” Media M onitors Network (March 18). Accessed at http://usa.mediamonitors.net/ content/view/full/27754 (June 25, 2019).

Naseem, Naheeda. 2014. "Geopolitical Value of Gwadar for the Region (Mainly for Pakistan, China and the Region)." South Asian Studies 29(2), 519-530.

Neo, Christabel. 2013. "China's Gwadar Pearl: The Port acquisition and implications for India." Institute of South Asian Studies Brief 288. Accessed at http://www.isas.nus..edu.sg. (November 27, 2019).

Nixon, Richard. 1980. The Real War. New York: A Warner Communication Company. . 1992. Seize the Moment. New York: Siman \& Schuster.

Pascu, Mihai. 2011. "The Geo-Strategic Importance of the Indian Ocean in the Context of the World Oil Crisis." Bulletin of the Transilvania University of Brasov 4(53), No. 1, Series V, 221-226.

Qasim, Ali. 2016. "Strategic Importance of Gwadar Port for Pakistan.” (April 17). Accessed at http://www.linkedin.com/pulse/strategic-importance-gwad ar-port-pakistan-qasim-ali/ (October 19, 2019).

Rana, Waheeda, and Hasan Mahmood. 2015. "Changing Dynamics of Pak- China Relations: Policy Recommendations for Pakistan.” American International Journal of Contemporary Research 5(2), 98-102.

Shahnaz, Iqra. 2015. "Gwadar Port: Challenges and Opportunities." (Feb 17). Accessed at http://www.incpak.com/editorial/gwadar-port-challengesopportunities/ (May 23, 2019).

Stopford, Martin. 2005. Maritime Economics. New York: Routledge.

Tanoli, Junaid. 2016. "Comparative Analysis of Gwadar and Chabahar: The Two Rival Ports." Centre for Strategic and Contemporary Research (CSCR). Accessed at http://www.cscr.pk (November 20, 2019).

Yan, Wong. 2012. "Securing the New Silk Route." (Feburary 17). Accessed at http:/ /www.newchinamag.com/magzine/securing-the-new-silk-route/ (Nove mber 23, 2019). 
Geostrategic Imperatives of Gwadar Port for China $\mid 167$

Yeuh-Yun, Leo. 1972. China as a Nuclear Power in World Politics. London: Palgrave Macmillan

[Received Feb 20, 2020; Revised Jul 20, 2020; Accepted Jul 21, 2020] 
